Received Date : 02-Jul-2014

Revised Date : 25-Sep-2014

Accepted Date : 01-Oct-2014

Article type : Original Scientific Article

\title{
Biocompatibility of new nanostructural materials based on active silicate systems and
}

hydroxyapatite: in vitro and in vivo study

V. Petrović ${ }^{1}$, V. Opačić-Galić ${ }^{1}$, S. Živković ${ }^{1}$, B. Nikolić ${ }^{2}$, V. Danilović ${ }^{1}$, V. Miletić ${ }^{1}$, V. Jokanović ${ }^{3}$, D. Mitić-Ćulafić

${ }^{I}$ Department for Restorative Dentistry and Endodontics, University of Belgrade, School of Dental Medicine, ${ }^{2}$ University of Belgrade, Institute for Nuclear Sciences Vinča, ${ }^{3}$ Department for microbiology, University of Belgrade, Faculty of Biology, Belgrade, Serbia

Running title: New material biocompatibility

Keywords: biocompatibility, calcium silicate, cytotoxicity, connective tissue, hydroxyapatite, inflammatory response

Corresponding author:

Dragana Mitić-Ćulafić

University of Belgrade - Faculty of Biology, Chair of microbiology, Studentski trg 16, 11000 Beograd, Serbia

This article has been accepted for publication and undergone full peer review but has not been through the copyediting, typesetting, pagination and proofreading process which may lead to differences between this version and the Version of Record. Please cite this article as an 'Accepted Article', doi: 10.1111/iej.12391

This article is protected by copyright. All rights reserved. 
tel/fax: +381112637364

e-mail: mdragana@bio.bg.ac.rs

\section{Abstract}

Aim To evaluate in vitro cytotoxicity and in vivo inflammatory response to new nanostructural materials based on active calcium silicate systems (CS) and hydroxyapatite (HA-CS).

Methodology Cytotoxicity of eluates of new nanostructural non-commercial materials CS and HA-CS, and MTA (White MTA, Angelus ${ }^{\circledR}$ Soluções Odontológicas, Londrina, Brazil) as a control, were tested using the MTT assay on MRC-5 cells. Eluates of set materials were tested in 100\% and 50\% concentrations, 24h, 7 days and 21 days post-elution. The $\mathrm{pH}$ values were determined for undiluted eluates of set materials. Polyethylene tubes containing the test materials (CS, HA-CS, MTA) were implanted in subcutaneous tissue of Wistar rats. Histopathological examinations were conducted at 7, 15, 30 and 60 days after the implantation. Data were statistically analyzed using three-way and one-way ANOVA Tukey's post-hoc test as well as Kruskall-Wallis test with Dunn's post-hoc test at $\alpha=0.05$.

Results All materials significantly reduced cell viability; especially when undilluted eluates were used ( $\mathrm{p}<0.001)$. After $24 \mathrm{~h}$ elution cell viability was $10 \pm 1.8 \%, 49.5 \pm 4.2 \%$ and $61 \pm 7.4 \%$, for MTA, CS and HA-CS, respectively. However, CS and HA-CS was significantly less toxic than the control material MTA $(\mathrm{p}<0.05)$. Cytotoxicity could be at least partially attributed to $\mathrm{pH}$ kinetics over time. Dilution of eluates of all tested materials resulted in better cell survival. Histopathological examination indicated similar inflammatory reaction, vascular congestion and connective tissue integrity associated with CS, HA-CS and MTA at each observation period $(\mathrm{p}>0.05)$. The only significant difference was found for capsule thickness, i.e. thicker capsule was associated with HA-CS compared to MTA at 60 days

This article is protected by copyright. All rights reserved. 
$(\mathrm{p}=0.0039)$. HA-CS induced moderately thick capsules (median score 3, score range 2-3) whereas MTA resulted in thin capsule formation (median score 2, score range 1-3).

Conclusions Evaluation of cytotoxicity and inflammatory response indicated better biocompatibility of CS and HA-CS, in comparison with MTA (White MTA, Angelus ${ }^{\circledR}$ Soluções Odontológicas, Londrina, Brazil).

\section{Introduction}

The potential use of calcium phosphate cements in endodontic therapy is an active area of research. Hydroxyapatite is one of the most commonly used calcium phosphate materials in medicine and dentistry. Biocompatibility of hydroxyapatite is closely related to its chemical composition, similar to dental and bony tissues. However, inferior mechanical properties limit the use of hydroxyapatite as an endodontic material. Recent studies have focused on new and modified formulations of calciumphosphate-based biomaterials with improved mechanical and maintained favorable biological properties (Huan \& Chang 2009, Khashaba et al. 2011, Damas et al. 2011, Modareszadeh et al. 2012, Chen et al. 2013, Hakki et al. 2013).

Recently, two non-commercial new materials based on calcium silicates and hydroxyapatite have been synthesized using two combined techniques - a hydrothermal sol-gel method and self-propagating combustion waves. One material is a calcium silicate system of tricalcium and dicalcium silicates (CS) and the other one is a mixture of the calcium silicate system and hydroxyapatite in 1:2 ratio (HA-CS). Barium sulphate was added for radiopacity. Both CS and HA-CS are nanostructural materials containing agglomerates, several micrometers in size, formed by smaller particles, $117-447 \mathrm{~nm}$ in size, which contain even smaller building blocks, 20 nm-sized crystallites (Opačić-Galić et al. 2013). Particle size affects cement hydration and consequently setting time and final quality of the cement. Smaller particles provide larger surface area available for hydration and speed up setting (Asgary et al. 2009). The nanostructure of 
the newly synthesized materials improves particle activity and shortens setting time to 10 minutes (CS) and 15 minutes (HA-CS) (Opačić-Galić et al. 2013). Fast setting is a clear clinical advantage whilst cement composition and internal nanostructure are expected to provide biological behavior in vital tissues.

The aim of this study was to evaluate the biocompatibility of new nanostructural materials based on calcium silicates (CS) and hydroxyapatite (HA-CS) by applying an in vitro cytotoxicity test, as well as in vivo histological responses to the materials. The results were compared with in vitro cytotoxicity and in vivo biocompatibility of MTA (White MTA, Angelus ${ }^{\circledR}$ Soluções Odontológicas, Londrina, Brazil), used as a control material.

\section{Materials and Methods}

The study was approved by the Ethical Committee of the School of Dental Medicine, University of Belgrade, Serbia (Protocol No. 36/5, 12/04/2012 and 36/21, 20/06/2013). All experimental procedures were conducted in accordance with ISO 10993-5, ISO 7405 and ISO 10993-2 specifications. CS and HACS were synthesized according to the protocol explained previously and mixed with distilled water in a powder-to-liquid ratio of 2:1 (Opačić-Galić et al. 2013). MTA (White MTA, Angelus ${ }^{\circledR}$ Soluções Odontológicas, Londrina, Brazil) was used as a control material. The powder-to-liquid ratio for MTA was 3:1 according to manufacturer's instructions.

Preparation of eluates of set materials

Prefabricated polyethylene moulds $5 \mathrm{~mm}$ in diameter and $2 \mathrm{~mm}$ deep, placed on sterile glass plates, were filled with unset materials CS, HA-CS and MTA, (12 replicas per material). Materials were left to set in an incubator at $37^{\circ} \mathrm{C}$ for $24 \mathrm{~h}$. After setting, the samples were sterilized under UV light (Laminar, BIO-CL-130, EHRET Gmbh\&CO.KG, Emmendingen, Germany). Eluates of materials were prepared by immersing each of them in $2 \mathrm{~mL}$ of DMEM, previously poured in a separate well of 12 well-

This article is protected by copyright. All rights reserved. 
culture plates (Sarstedt Inc, Newton, NC, USA).The ratio between the surface of the samples and the volume of medium was approximately $71 \mathrm{~mm}^{2} / \mathrm{mL}$. Eluation were performed without medium changing in an atmosphere with $5 \% \mathrm{CO}_{2}$ at $37^{\circ} \mathrm{C}$ for $24 \mathrm{~h}, 7$ and 21 days, for cytotoxicity testing, and for $24 \mathrm{~h}, 4,7$

and 21 days, for $\mathrm{pH}$ analysis. For cytotoxicity testing, undiluted eluates (100\% concentration) and dilluted ones ( $50 \%$ concentration) were used, both sterilized by filtration through $0.45 \mu \mathrm{m}$ Cronus Sterile Syringe filters (SMI-Labhut Ltd, Gloucester, UK).

\section{Cell culture}

Human lung fibroblasts MRC-5 (ECACC No84101801) were grown in $75 \mathrm{~cm}^{2}$ culture plates (Sarstedt Inc, Newton, NC, USA) in DMEM supplemented with 10\% fetal bovine serum, containing 2 $\mathrm{mM}$ of L-glutamine and $100 \mathrm{IU} / \mathrm{mL}$ penicillin/streptomycin at $37^{\circ} \mathrm{C}$ in a humidified incubator containing $5 \% \mathrm{CO}_{2} / 37^{\circ} \mathrm{C}$ (MRC Scientific instruments, Holon, Israel). Confluent monolayer of cells, verified under light microscope (Boeko, Hamburg, Germany), were washed with phosphate-buffered saline (PBS), detached with $0.25 \%$ trypsin, centrifuged and re-suspended in medium. The cells were then seeded in 96well plates, $\left(1 \times 10^{4}\right.$ cells $/ 200 \mu \mathrm{L}$ medium/well $)$ and incubated for $24 \mathrm{~h}$ to form cell monolayer before its exposure to test materials. All manipulations with cells were done under aseptic conditions (Laminar, BIO-CL-130, EHRET Gmbh\&CO.KG, Emmendingen, Germany).

Cytotoxicity test

The cytotoxicity of eluates was determined by MTT reduction assay (Hansen et al. 1989) using the 1-(dimethyltiazol-2-yl)-2,5 diphenyl tetrazolium bromide (MTT) as an indicator of cell viability. This colorimetric method is based on reduction of tetrazolium compound into colored formazan product by mitochondrial dehydrogenases in viable and active cells. For each test material, both $100 \%$ and $50 \%$ eluates were tested in two independent experiments with six wells per treatment point.

This article is protected by copyright. All rights reserved. 
After 20h incubation of cells in eluates of materials prepared in DMEM the medium was removed and cells were washed with PBS. The MTT in final concentration $0.5 \mathrm{mg} / \mathrm{mL}$ (Sigma Chemical Co., St Louis, MO, USA) was then added and the plates were incubated for additional $3 \mathrm{~h}$. The MTT solution was then carefully removed and the formazan crystals were dissolved in dimethyl-sulphoxyde. Cell viability was determined by measuring the absorbance at $570 \mathrm{~nm}$, using a Micro-plate reading Spectrophotometer (Thermo, Scientific Multiscan FC, Vantaa, Finland). The relative cell viability of the test materials was calculated as follows:

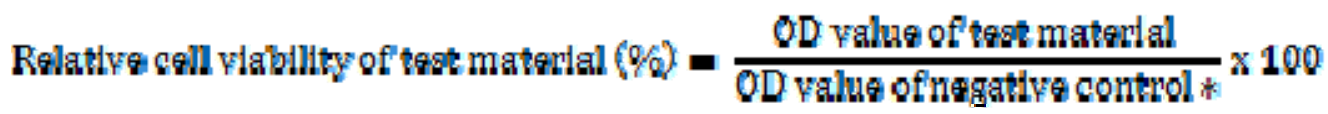

* Untreated cells served as negative control.

$\mathrm{pH}$ analysis

$\mathrm{pH}$ analysis of undiluted eluates was performed within $24 \mathrm{~h}, 4,7$ and 21 days, using a calibrated pH meter (Cyberscan pH 510, Eutech Instruments Europe B.V, Landsmeer, The Netherlands).

Experimental design for subcutaneous implantation

Forty Wistar albino male rats, a mean weight $350 \mathrm{~g}$, were selected and randomly divided into four groups $(n=10)$. The animal received intraperitoneal injection of $75 \mathrm{mg} / \mathrm{kg}$ ketamine and $5 \mathrm{mg} / \mathrm{kg}$ of body weight of diazepam. After shaving the backs of animals, skin was disinfected by iodine tincture. Two incisions on both sides of spinal cord in a head-tail direction, $15 \mathrm{~mm}$ in length were created using the scalpel blade. Two pockets, $15 \mathrm{~mm}$ deep, were than prepared by blunt dissection. Samples of freshly mixed materials was placed in one half of a sterile polyethylene tube, $10 \mathrm{~mm}$ long and with $1 \mathrm{~mm}$ inner diameter, while the other half remained empty and served as a negative control. The tubes were implanted subcutaneously in the previously prepared pocket and the incisions were sutured using single resorbable sutures. Each animal received two tubes: on the right side the one filled with the test material (CS or HACS), and on the left side the one filled with MTA, used as a control material.

This article is protected by copyright. All rights reserved. 
Animals were sacrificed in groups of ten after 7, 15, 30 and 60 days ( 5 animal per tested material), using a high dose of anaesthetic. The tubes were removed along with surrounding connective tissue. Samples were fixed in $10 \%$ formalin solution. The tissue was cut in 4 micrometers thick sections, stained with haematoxylin and eosin and analyzed histologically.

A modified criterion described by Lotfi et al. (2009) and Scarparo et al. (2010) was used for evaluation of tissue reaction. Slides were analyzed qualitatively and semi-quantitively under a light microscope (Olympus BX-51, Tokyo, Japan) at x40, x100 and x400 magnification. The cellular inflammatory component was determined by the presence of neutrophils, lymphocytes, plasmacytes, macrophages and giant cells. Quantitative evaluations of inflammatory cells were made in four separate areas. The inflammatory reactions were categorized as 0 or none (without inflammatory cells), 1 or minimal (inflammatory cells<25), 2 or mild (26-50 inflammatory cells), 3 or moderate (51-100 inflammatory cells), and 4 or severe (more than 100 inflammatory cells). Fibre condenzation were classified according to the following scale: 0 - absence of collagen fibre, 1 - presence of a minimal layer of collagen fibre, 2 presence of a thin layer of collagen fibre, 3 - presence of a thick layer of collagen fibre and 4 - large capsule.

\section{Statistical analysis}

The data for the cytotoxicity of eluates were analyzed statistically using three-way ANOVA for the factors 'material', 'concentration' and 'time'. Interactions between the factors were also tested. Differences for each material across time periods were tested using repeated measures ANOVA. When it was necessary, i.e. interaction was significant, one-way ANOVA with Tukey's post-test was used to test differences between materials at each concentration / time.

This article is protected by copyright. All rights reserved. 
For histological analyzes one-way analysis of variance (non-parametric ANOVA, Kruskal-Wallis test) was used to analyze differences between the treatments within each experiment. Dunn's Post Test was used to compare the differences between groups. Statistical analysis was performed in Minitab 16 (Minitab Inc. State College, PA, USA).

\section{Results}

\section{Cytotoxic potential of nanomaterials}

The results of cytotoxicity of eluates are presented in Fig. 1. Cell viability following exposure to undiluted eluates $(100 \%)$ of all materials was significantly lower in comparison with untreated control at all time periods $(\mathrm{p}<0.001)$. There were no significant differences in cell viability following exposure to CS and HA-CS eluates at $24 \mathrm{~h}$ and 7 days ( $\mathrm{p}>0.05)$. In 21-day eluates, cell viability was greater after treatment with HA-CS than with CS ( $\mathrm{p}<0.001)$. In $100 \%$ concentration, MTA eluates resulted in significantly lower cell viability compared to CS and HA-CS eluates at all test periods $(\mathrm{p}<0.001)$. Cytotoxicity of $100 \%$ MTA eluates increased over time and was greater after 21 days elution, compared to previously performed $(24 \mathrm{~h}$ and 7 days $)(\mathrm{p}<0.001)$. Dilution of all eluates resulted in significantly lower toxicity in comparison to undiluted ones but cell viability was still lower than in the untreated group $(\mathrm{p}<0.001)$.

The highest $\mathrm{pH}$ values of all materials was obtained after 7 days, and virtually no further changes were observed for CS and MTA, whilst HA-CS showed a slight decreasing tendency over time (Fig. 2). Inflammatory response to nanomaterials

The histological micrographs (20 microscope slides were prepared in duplicate for each material/evaluation period) are presented in Fig. 3. The parameters of inflammation response and thickness of formed fibrous capsule are estimated and presented in Table 1.

This article is protected by copyright. All rights reserved. 
Seven days after implantation the intensity of the inflammatory reaction in connective tissue around the implant (Fig. 3A, Table 1) was estimated as moderate for all materials. The histological data obtained for negative controls showed mild inflammatory reaction with destruction of collagen fibres but without necrosis. The increased number of blood vessels indicated formation of granulation tissue and repair. Furthermore, thin fibrous capsules were observed around all materials, as well as around control parts of the tubes.

The micrographs of tissue after 15 days of implantation showed mild inflammation associated with all materials and the negative control (Fig. 3B, Table 1). Connective tissue contained the usual number of blood vessels with minimal signs of venous stasis. The integrity of pericapsular connective tissue was disturbed only minimally, with small numbers of lymphocytes and plasma cells. A thin capsule was formed around the implant tubes while inflammatory cells were not detected in the capsule. The thickness of capsules was most pronounced for HA-CS implants, and the thinnest for the negative control (empty tubes).

Thirty days after implantation the connective tissue exhibited signs of good recovery with minimal numbers of inflammatory cells for all materials, (Fig 3C, Table 1). Furthermore, capsules around all implants were well-developed and no significant differences were observed between them.

At the end of the evaluation period (60 days) a well-developed fibrous capsules were formed around all implants, furthermore the common structure and number of blood vessels was detected, almost without signs of inflammation (Fig 3D, Table 1). The calming of inflammation and the best formed capsule were the most notable for HA-CS implant. The difference in the thickness of the capsule between HA-CS and MTA was significant $(\mathrm{p}=0.0039)$.

This article is protected by copyright. All rights reserved. 


\section{Discussion}

An excellent tissue biocompatibility of endodontic cements materials is desirable for clinical use, since these materials come into direct contact with living connective tissues. Ideally, a good endodontic cement material should be biologically compatible and well tolerated, avoiding any possible interference and/or delay of the healing process (Testarelli et al. 2012).

In the present study, initial screening of in vitro cytotoxicity of two experimental materials and MTA, used as the control material, was performed using the MTT assay, one of the most commonly used tests for evaluation of material toxicity in a cell culture (Damas et al. 2011, Gomes Cornelio et al. 2011, De Deus et al. 2005, Modareszadeh et al. 2011). Cytotoxicity of undiluted (100\%) and diluted (50\%) eluates from set materials was measured at three time intervals to evaluate dependency of material toxicity and concentration and to follow toxicity over time. The use of eluates for cytotoxicity testing is a routine method for in vitro evaluation of potential toxic effect of leachable ingredients and by-products. This approach may be considered as a simplified in vitro simulation of clinical conditions, since leachable substances may elute out from the material after its in vivo application (Modareszadeh et al. 2011).

In general, CS and HA-CS eluates had lower cytotoxicity than MTA eluates. Previous studies have shown variable results regarding the peak of cytotoxicity of MTA which spanned from the lack of any effect on cell viability (Damas et al. 2011, Modareszadeh et al. 2012), to measurable cytotoxic effects after 24h (De Deus et al. 2005) and 14 days post-exposure (Modareszadeh et al. 2011). Similarly, some authors have reported increased cytotoxicity over time (De Deus et al. 2009, Karimjee et al. 2006), whilst others found variable cytotoxic effects of different MTA-based commercial materials (Lee et al. 2012). Difference in the cell line used, in the protocols for material preparation and setting, in the ratio of sample surface area and volume of the elution medium, in duration of exposure, as well as in the monitored parameters of cell viability, may account for variable results of the aforementioned studies.

This article is protected by copyright. All rights reserved. 
The present $\mathrm{pH}$ data indicates different ion elution kinetics, as well as different ion concentrations eluted from the test materials. The highest and most rapid ion release was found for MTA which is in agreement with the findings of Duarte et al. (2003), reporting high $\mathrm{pH}$ value of MTA eluates prepared in distilled water over 7 days. Formosa et al. (2013) reported high pH value of calcium silicate-based cement eluates in simulated tissue fluid after 28 days. Cytotoxicity of the materials could be associated with $\mathrm{pH}$ values obtained at the corresponding time point. Cytotoxicity of MTA corresponded well with high pH observed in this study. The dynamics of $\mathrm{pH}$ and cytotoxicity of undiluted CS eluates corresponded to each other: they increased over first 7 days and were maintained at high levels up to 21 day. Similarly, undiluted HA-CS eluates exhibited the same relationship between $\mathrm{pH}$ values and cytotoxicity: at the 21 days both $\mathrm{pH}$ values and cytotoxicity were decreased.

Despite the similar calcium silicate nature of MTA and CS, the greater cytotoxicity of MTA could be related to differences in radiopacifying agents. CS contains barium sulfate, a well-known radiopaque contrast medium used in medicine, whereas MTA contains bismuth oxide (Camilleri \& Ford, 2006). Bismuth oxide interferes with MTA hydration, becomes a constituent of calcium silicate hydrate and may elute along with calcium hydroxide from set MTA (Camilleri 2008). Gomes Cornelio et al. (2011) reported the effects of radiopacifying agents, including bismuth oxide, on cytotoxicity of Portland cement. They detected that Portland cement alone was not cytotoxic even at high concentrations (100 $\mathrm{mg} / \mathrm{mL}$ ) whereas its cytotoxicity significantly increased after addition of radiopacifying agents.

It needs to be emphasized that nanostructural materials do not have heavy metals in their composition. Furthermore, structures built on three hierarchical levels (agglomerates, particles and crystallites) could be especially promising. Dimensions of agglomerates are not comparable with dimensions of membrane channels, preventing harmful biological effects, whereas their nano-elements (nano-crystallites) provide evident improvements to settings characteristics.

This article is protected by copyright. All rights reserved. 
Lower cytotoxicity of HA-CS compared to CS, and especially to MTA, could be associated with lower $\mathrm{pH}$ and the presence of hydroxyapatite, the main ingredient into which calcium silicate is added to improve mechanical properties (Huan \& Chang, 2009). Beside lower cytotoxicity found in the present study, HA-CS has previously been related to have lower genotoxic potential in human lymphocytes (Opačić-Galić et al. 2013).

The histological response of tissue to the biomaterials is one of the most important criteria for biocompatibility determination, as well as the dynamics of fibrose capsule formation over 60 days, as a good marker of tissue recovery (Lotfi et al. 2009, Martinez et al. 2009, Yavari et al. 2009, Khashaba et al. 2011, Silva-Herzog et al. 2011, Parirokh et al. 2011, Gomes-Filho et al. 2012). Histological examination was performed 7, 15, 30, and 60 days after implantation. The regions around CS and HA-CS implants exhibited the most notable inflammatory reaction within 7 days, with moderate disturbance of connective tissue. After that period, the intensity of inflammation induced by CS and HA-CS decreased up to $30^{\text {th }}$ day, and dramatically decreased in subsequent periods, resulting in negligible inflammation at $60^{\text {th }}$ day. The tissue around the part of tube with MTA showed the most evident signs of inflammation, which was characterized as pronounced at $7^{\text {th }}$ day, moderate at the $15^{\text {th }}$ and $30^{\text {th }}$ day and negligible at the $60^{\text {th }}$ day. Similar tissue response was reported by Parirokh et al. (2011), who observed coagulation necrosis and dystrophic calcification. High inflammatory reaction induced by MTA could be a consequence of the high $\mathrm{pH}$ of mixed MTA and heat released during the binding of MTA. It is known that high $\mathrm{pH}$ and heat release can stimulate induction of inflammatory cytokines (interleukins 1 and 6) which contributes to the strong inflammatory response of tissues (Moretton et al. 2000, Modaresi et al. 2005, Camilleri and Ford 2006, Lotfi et al. 2009). With the reduction of inflammation, formation of good organized fibrous capsule was observed for all materials. The best developed capsule was detected for HA-CS, indicating well tolerance of tissue to this material. However, the difference between tissue response obtained for empty part of tubes, used as negative controls, and for tested materials, indicated that MTA, CS, and especially HA-CS, did not significantly contribute to the inflammation reaction. The similar results corresponding

This article is protected by copyright. All rights reserved. 
tissue reaction to the control tubes have already been reported (Vosoughhosseini et al. 2008; Yavari et al. 2009; Gomes-Filho et al. 2012).

CS and especially HA-CS, induced significantly lower cytotoxicity in comparison with MTA, which could be associated with slower ion elution and steady $\mathrm{pH}$ values. Both experimental materials exhibited dose-dependent cytotoxicity. The results obtained from histological examination showed that CS, and especially HA-CS, induced significantly less inflammation than MTA, which disappeared 60 days after implantation. Taking into account previously reported data, indicating good mechanical properties, short setting time, and low genotoxicity (Opačić-Galić et al. 2013), as well as significantly lower cytotoxicity and inflammation, i.e. better biocompatibility than MTA, both nanostructural biomaterials based on active silicate systems and hydroxyapatite, especially HA-CS, could be candidates for future clinical studies.

\section{Conclusions}

Evaluation of cytotoxicity and inflammatory response indicated better biocompatibility of CS and HA-CS, in comparison with MTA (White MTA, Angelus ${ }^{\circledR}$ Soluções Odontológicas, Londrina, Brazil)

\section{Acknowledgements}

This research was financially supported by the Ministry of Education and Science of the Republic of Serbia; projects No 172007.

\section{References}

Asgary S, Eghbal MJ, Parirokh M, Ghoddusi J, Kheirieh S, Brink F (2009) Comparison of mineral trioxide aggregate's composition with Portland cements and a new endodontic cement. Journal of Endodontics 35, 243-50.

This article is protected by copyright. All rights reserved. 
Camilleri J, Ford TRP (2006) Mineral trioxide aggregate: a review of the constituents and biologocal properties of the material. International Endodontic Journal 39, 747-54.

Camilleri J (2008) Characterization of hydration products of mineral trioxide aggregate. International Endodontic Journal 41, 408-17.

Chen YZ, Lu XY, Liu GD (2013) A novel root-end filling material based on hydroxyapatite, tetracalcium phosphate and polyacrylic acid. International Endodontic Journal 46, 556-64.

Damas BA, Wheater MA, Bringas JS, Hoen MM (2011) Cytotoxicity comparison of mineral trioxide aggregates and EndoSequence bioceramic root repair materials. Journal of Endodontics 37, 372-5.

De Deus G, Ximenes R, Gurgel-Filho ED, Plotkowski MC, Coutinho-Filho T (2005) Cytotoxicity of MTA and Portland cement on human ECV 304 endothelial cells. International Endodontic Journal 38, 604-9.

De Deus G, Canabarro A, Alves G, Linhares A, Senne MI, Granjeiro JM (2009) Optimal cytocompatibility of a bioceramic nanoparticulate cement in primary human mesenchymal cells. Journal of Endodontics 35, 1387-90.

Duarte MA, Demarchi AC, Yamashita JC, Kuga MC, Fraga Sde C (2003) pH and calcium ion release of 2 root-end filling materials. Oral Surgery Oral Medicine Oral Pathology Oral Radiology and Endodontics 95, 345-7.

Formosa LM, Mallia B, Camilleri J (2013) Mineral trioxide aggregate with anti-washout gel - properties and microstructure. Dental Materials 29, 294-306.

Gomes Cornelio AL, Salles LP, Campos da Paz M, Cirelli JA, Guerreiro-Tanomaru JM, Tanomaru Filho M (2011) Cytotoxicity of Portland cement with different radiopacifying agents: a cell death study. Journal of Endodontics 37, 203-10.

Gomes-Filho JE, Watanabe S, Simonetti Lodi C et al. (2012) Rat tissue reaction to MTA FILLAPEX. Dental Traumatology 28, 452-6.

This article is protected by copyright. All rights reserved. 
Hakki SS, Bozkurt BS, Ozcopur B, Gandolfi MG, Prati C, Belli S (2013) The response of cementoblasts to calcium phosphate resin-based and calcium silicate-based commercial sealers. International Endodontic Journal 46, 242-52.

Hansen MB, Nielsen SE, Berg K (1989) Re-examination and further development of a precise and rapid dye method for measuring cell growth/cell kill. Journal of Immunol Methods 119, 203-10.

Huan Z, Chang J (2009) Calcium-phosphate-silicate composite bone cement: self-setting properties and in vitro bioactivity. Journal of Material Science. Materials in Medicine 20, 833-41.

Karimjee CK, Koka S, Rallis D.M., Gound TG (2006) Cellular toxicity of mineral trioxide aggregate mixed with an alternative delivery vehicle. Oral Surgery Oral Medicine Oral Pathology Oral Radiology and Endodontics 102, e115-20.

Khashaba RM, Moussa MM, Chutkan NB, Borke JL (2011) The response of subcutaneous connective tissue to newly developed calcium phosphate-based root canal sealers. International Endodontic Journal 44, $342-52$.

Lee BN, Son HJ, Noh HJ, Koh JT, Chang HS, Hwang IN et al. (2012) Cytotoxicity of newly developed ortho MTA root-end filling materials. Journal of Endodontics 38, 1627-30.

Lotfi M, Vosoughhosseini S, Saghiri MA, Mesgariabbasi M, Ranjkesh B (2009) Effect of White Mineral Trioxide Aggregate Mixed With Disodium Hydrogen Phosphate on Inflammatory Cells. Journal of Endodontics 35, 703-5.

Martinez LR, Esain ML, Kokubu GA, Willis J, Chaves C, Grana DR (2009) Rat Subcutaneous Tissue Response to Modified Portland Cement, a New Mineral Trioxide Aggregate. Brazilian Dental Journal 20, 112-7.

Modareszadeh MR, Chogle SA, Mickel AK, Jin G, Kowsar H, Salamat N et al. (2011) Cytotoxicity of set polymer nanocomposite resin root-end filling materials. International Endodontic Journal 44, 154-61.

Modareszadeh MR, Di Fiore PM, Tipton DA, Salamat N (2012) Cytotoxicity and alkaline phosphatase activity evaluation of EndoSequence root repair material. Journal of Endodontic 38, 1101-5.

This article is protected by copyright. All rights reserved. 
Modaresi J, Yavari AS, Diant O, Shahrabi S (2005) A comparison of Tissue Reaction to MTA and an Experimental Root-End Restorative Material in Rats. Australian Endodontic Journal 31, 69-72.

Moretton TR, Brown CE Jr, Legan JJ, Kafrawy AH (2000) Tissue reactions after subcutaneous and intraosseous implantation of mineral trioxide aggregate and ethoxybenzoic acid cement. Journal of Biomedical Materials Research Part A 52, 528-33.

Opačić-Galić V, Petrović V, Zivković S et al. (2013) New nanostructural biomaterials based on active silicate systems and hydroxyapatite: characterization and genotoxicity in human peripheral blood lymphocytes. International Endodontic Journal 46, 506-16.

Parirokh M, Mirsoltani B, Raoof M, Tabrizchi H, Haghdoost AA (2011) Comparative study of subcutaneous tissue responses to a novel root-end filling material and white and grey mineral trioxide aggregate. International Endodontic Journal 44, 283-9.

Scarparo RK, Haddad D, Acasigua GAX, Fossati ACM, Fachin EVF, Grecca FS (2010) Mineral Trioxide Aggregate-based Sealer: Analysis of Tissue Reactions to a New Endodontic Material. Journal of Endodontics 36, 1174-8.

Silva-Herzog D, Ramirez T, Mora J et al. (2011) Preliminary study of the inflammatory response to subcutaneous implantation of three root canal sealers. International Endodontic Journal 44, 440-6.

Testarelli L, Nocca G, Lupi A et al. G (2012) Biocompatibility of root canal filling materials: differences between vitality and functionality tests. European Journal of Inflammation 10, 105-10.

Vosoughhosseini S, Lotfi M, Shabi S et al., (2008) Influence of White versus Gray Mineral Trioxide Aggregate on Inflammatory Cells. Journal of Endodontics 34, 715-7.

Yavari HR, Shahi S, Rahimi S et al. (2009) Connective tissue reaction to white and gray MTA mixed with distilled water or chlorhexidine in rats. International Endodontic Journal 4, 25-30.

This article is protected by copyright. All rights reserved. 


\section{Figure legends}

Figure 1 Cell viability following exposure to undiluted (100\%) and diluted (50\%) eluates of set materials. Upper case letters indicate statistical differences between materials at one test period (e.g. MTA at $24 \mathrm{~h}$ versus CS at $24 \mathrm{~h}$ versus HA-CS at $24 \mathrm{~h}$ ); groups with the same letter are not significantly different ( $>0.05)$. Lower case letters indicate statistical differences within one material at different test periods; groups with the same letter are not significantly different $(p>0.05)$. Asterisks indicate statistical differences between undiluted (100\%) and diluted $(50 \%)$ eluates of the same material at the same test period $(\mathrm{p}<0.05)$.

Figure 2 Kinetics of $\mathrm{pH}$ values of eluates from set materials over 21 days.

Figure 3 The effect of nanomaterials on the inflammation induction 7 (A), 14 (B), 30 (C) and 60 (D) days of exposure. A a) CS: moderate inflammatory reaction with rare appearance of monocytes, lymphocytes and granulocytes in inflammatory infiltrate; gentle, very thin capsule (arrows) around the implant was observed (HE, $400 \mathrm{x})$. b) HA-CS: connective tissue revealed normal histological structure, without signs of necrosis, infection or inflammation. Connective tissue was composed of normal collagen fibers, fibroblasts and minor number of inflammatory cells, suggesting biocompatibility of applied material (HE, $400 \mathrm{x}$ ). c) MTA: pericapsular connective tissue with a marked inflammatory response and prominent venous stasis (VS); gentle, very thin capsule around the implant was observed (HE, $400 \mathrm{x}$ ). d) Negative control (empty tube): the integrity of connective tissue (CT) was weakly disrupted, the inflammatory infiltrate was dominated by lymphocytes and plasmacytes (HE, 400x).

B a) CS: mild inflammatory reaction, the connective tissue (CT) is mostly preserved integrity. The presence of lymphocytes and plasma cells indicated the chronic inflammatory reaction (HE, 400x). b) HA-CS: mild inflammatory reaction and well developed capsule (arrows) were observed in HA-CS sample, with perivascular and subcapsular inflamatory infiltrate consisted of lymphocytes and plasma cells in the connective tissue (HE, 400x). c) MTA: moderate inflammation, connective tissue exhibited mildly impaired integrity (CT) (HE, 400x). d) Negative control (empty tube): the integrity of connective

This article is protected by copyright. All rights reserved. 
tissue was weakly disrupted. A number of blood vessels (arrows) were observed in pericapsular connective tissue confirming the neoangiogenesis (HE, 400x).

C a) CS: the connective tissue with well-preserved structures; well-developed capsule around the implant (HE, 100x). b) HA-CS: the pericapsular connective tissue integrity was preserved with no signs of vascular congestion; very well-developed capsule around the implant (HE, 100x). c) MTA: Histological analysis showed presence of well developed, dense collagen capsule (arrow). Histological structure of underlying connective tissue was completely maintained without signs of inflammation. (HE, 100x). d) Negative control (empty tube): Well organized capsule (arrow), composed of parallel and thick collagen fibers was observed, separating implanted tube from surrounding tissue. Underlying connective tissue revealed normal histological organization with minimal inflammatory cells. (HE, 100x).

D a) CS: the integrity of connective tissue (SCT) was well preserved; well-developed capsule (arrows) around the implant (HE, 100x). b) HA-CS: the integrity of connective tissue (SCT) was well preserved; very well-developed capsule (arrows) around the implant (HE, 100x). c) MTA: the connective tissue (SCT) was with the preserved integrity; capsule (arrows) was well-formed but thinner in comparison with CS and especially HA-CS (HE, 100x). d) Negative control (empty tube): the integrity of connective tissue was well preserved; capsule (arrows) was well-developed (HE, 100x).

This article is protected by copyright. All rights reserved. 
Table 1 Histological analysis of the effect of nanomaterials

\begin{tabular}{|c|c|c|c|c|c|c|c|c|c|c|c|c|c|c|c|}
\hline \multirow{2}{*}{ Reaction } & \multicolumn{2}{|c|}{ CS } & \multicolumn{2}{|c|}{ CS-control } & \multicolumn{2}{|c|}{ HA-CS } & \multicolumn{2}{|c|}{$\begin{array}{l}\text { HA-CS- } \\
\text { control }\end{array}$} & \multicolumn{2}{|c|}{ MTA } & \multicolumn{2}{|c|}{$\begin{array}{l}\text { MTA- } \\
\text { control }\end{array}$} & \multirow{2}{*}{$\begin{array}{c}\text { p- } \\
\text { value }\end{array}$} & \multirow{2}{*}{\multicolumn{2}{|c|}{$\begin{array}{l}\text { Intra-group p- } \\
\text { value }\end{array}$}} \\
\hline & $\begin{array}{l}\text { Score } \\
\text { range }\end{array}$ & Med & $\begin{array}{l}\text { Score } \\
\text { range }\end{array}$ & Med & $\begin{array}{l}\text { Score } \\
\text { range }\end{array}$ & Med & $\begin{array}{l}\text { Score } \\
\text { range }\end{array}$ & Med & $\begin{array}{l}\text { Score } \\
\text { range }\end{array}$ & Med & $\begin{array}{l}\text { Score } \\
\text { range }\end{array}$ & Med & & & \\
\hline \multicolumn{16}{|c|}{$\begin{array}{l}\text { Inflammatory } \\
\text { reaction }\end{array}$} \\
\hline 7 days & $2-4$ & 3 & $2-4$ & 3 & $2-4$ & 3 & $2-4$ & 3 & $3-4$ & 3 & $1-4$ & 3 & 0.637 & & \\
\hline 15 days & $1-3$ & 2 & $1-4$ & 2 & $1-2$ & 2 & $1-3$ & 2 & $1-4$ & 2.5 & $1-3$ & 2 & 0.567 & & \\
\hline 30 days & $1-2$ & 2 & $0-2$ & 1 & $1-2$ & 1 & $1-2$ & 1 & $0-3$ & 2 & $1-2$ & 1.5 & 0.233 & & \\
\hline 60 days & $0-1$ & 0.5 & $0-1$ & 0.5 & $0-1$ & 0 & $0-1$ & 0 & $0-2$ & 0 & $0-3$ & 0 & 0.764 & & \\
\hline \multicolumn{16}{|c|}{$\begin{array}{l}\text { Vascular } \\
\text { congestion }\end{array}$} \\
\hline 7 days & $2-3$ & 3 & $3-4$ & 3 & $0-4$ & 3 & $2-4$ & 2.5 & $1-3$ & $2 *$ & $0-4$ & $3^{*}$ & 0.098 & $0.0128 *$ & \\
\hline 15 days & $1-3$ & 1 & $0-3$ & 2 & $0-3$ & 0 & $0-3$ & 1 & $0-3$ & 1.5 & $0-2$ & 1 & 0.563 & & \\
\hline 30 days & $0-1$ & 1 & $0-1$ & 0 & $0-1$ & 1 & 0 & 0 & $0-2$ & $1 *$ & $0-1$ & $\mathbf{0}^{*}$ & 0.112 & $0.0275^{*}$ & \\
\hline 60 days & 0 & 0 & 0 & 0 & 0 & 0 & 0 & 0 & $0-1$ & 0 & $0-1$ & 0 & 0.787 & & \\
\hline \multicolumn{16}{|l|}{$\begin{array}{c}\text { Capsule } \\
\text { thickness }\end{array}$} \\
\hline 7 days & $1-3$ & 1 & $0-2$ & 1 & $0-3$ & 2.5 & $1-2$ & 1.5 & $0-3$ & 2 & $0-3$ & 1.5 & 0.377 & & \\
\hline 15 days & 2 & 2 & $1-2$ & 2 & $1-3$ & 2 & $1-2$ & 2 & $1-3$ & 2 & $1-2$ & 2 & 0.265 & & \\
\hline 30 days & $1-3$ & 2 & $1-3$ & 2 & $2-3$ & 3 & $1-3$ & 2 & $1-3$ & 2 & $2-3$ & 2 & 0.397 & & \\
\hline 60 days & $2-3$ & 2 & $1-2$ & 2 & $2-3$ & $3 * * *$ & $2-3$ & $2 *$ & $1-3$ & $2 * *$ & $2-3$ & 2 & 0.05 & $0.0027 *$ & $0.0039^{* * *}$ \\
\hline \multicolumn{16}{|c|}{$\begin{array}{c}\text { Connective } \\
\text { tissue } \\
\text { integrity }\end{array}$} \\
\hline 7 days & $2-3$ & 3 & $1-4$ & 4 & $2-3$ & 2.5 & $1-3$ & 2 & $1-4$ & 3 & $0-3$ & 3 & 0.778 & & \\
\hline 15 days & $1-3$ & 1 & $0-3$ & 2 & $0-3$ & 1 & $1-3$ & 2 & $0-3$ & 2 & $0-3$ & 1.5 & 0.963 & & \\
\hline 30 days & $0-2$ & 1 & $0-2$ & 1 & $0-1$ & 0 & $0-2$ & 1 & $0-2$ & 1 & $0-1$ & 1 & 0.258 & & \\
\hline 60 days & 0 & 0 & $0-1$ & 0 & 0 & 0 & 0 & 0 & $0-1$ & 0 & $0-1$ & 0 & 0.321 & & \\
\hline
\end{tabular}

Med-Median. Within a row, bolded cells with the same superscript are significantly different and matched with the intragroup p-value with the same superscript.

Inflammatory reaction: 0 -absent, 1 -minimum $<25$ cells, 2-mild 26-50 cells, 3-moderate $51-100$ cells, 4pronounced >100 cells; Vascular congestion: 0-absent, 1-minimum, 2-mild, 3-moderate, 4-pronounced, reaction with firing of blood vessels; Capsule: 0-- absent, 1-minimum, 2-thin, 3-moderately thick, 4-thick; Connective tissue integrity: 0-complete integrity, 1-minimal disruption, 2-mild disruption, 3-moderate disruption, 4-necrosis.

This article is protected by copyright. All rights reserved. 


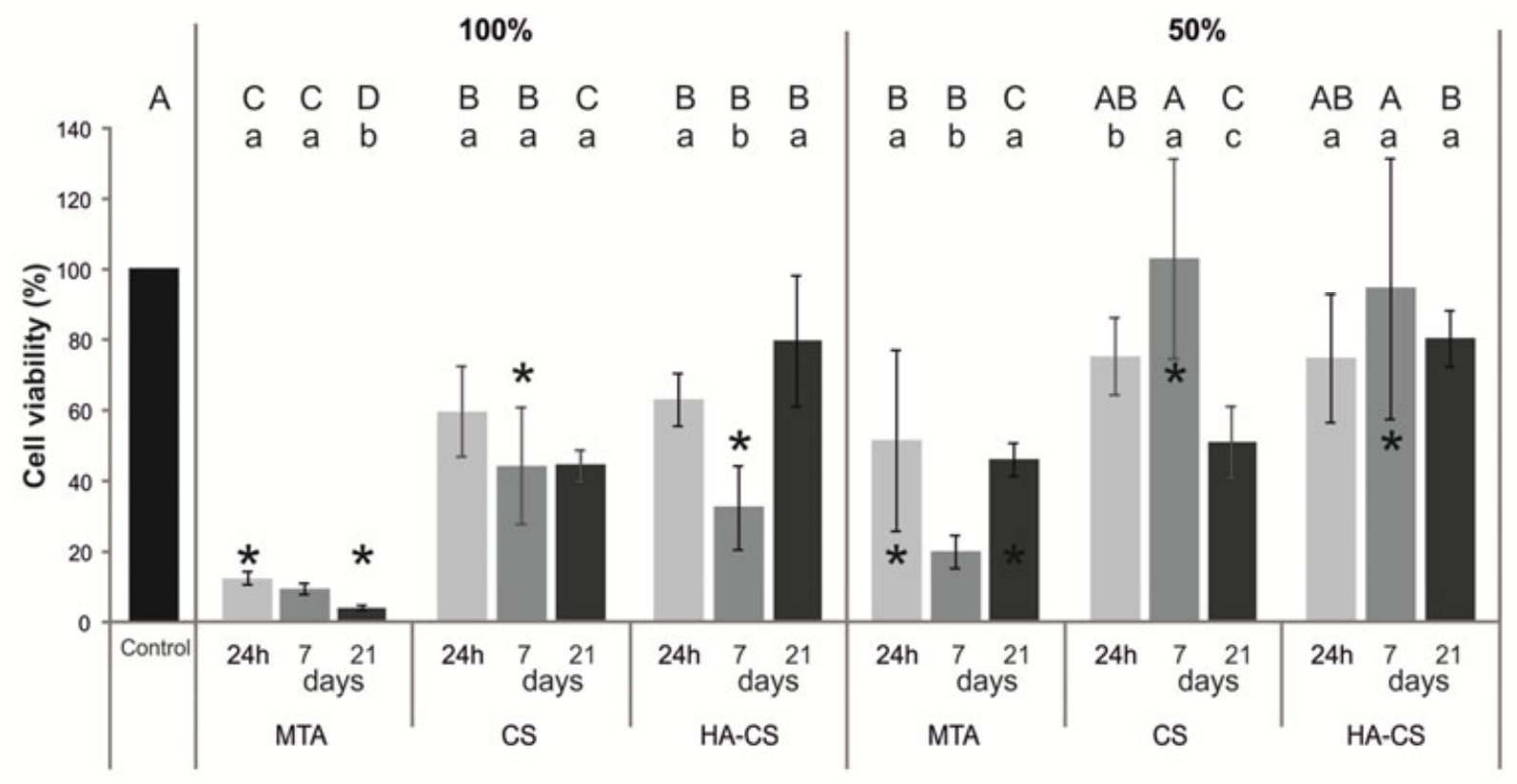

Eluates of set materials

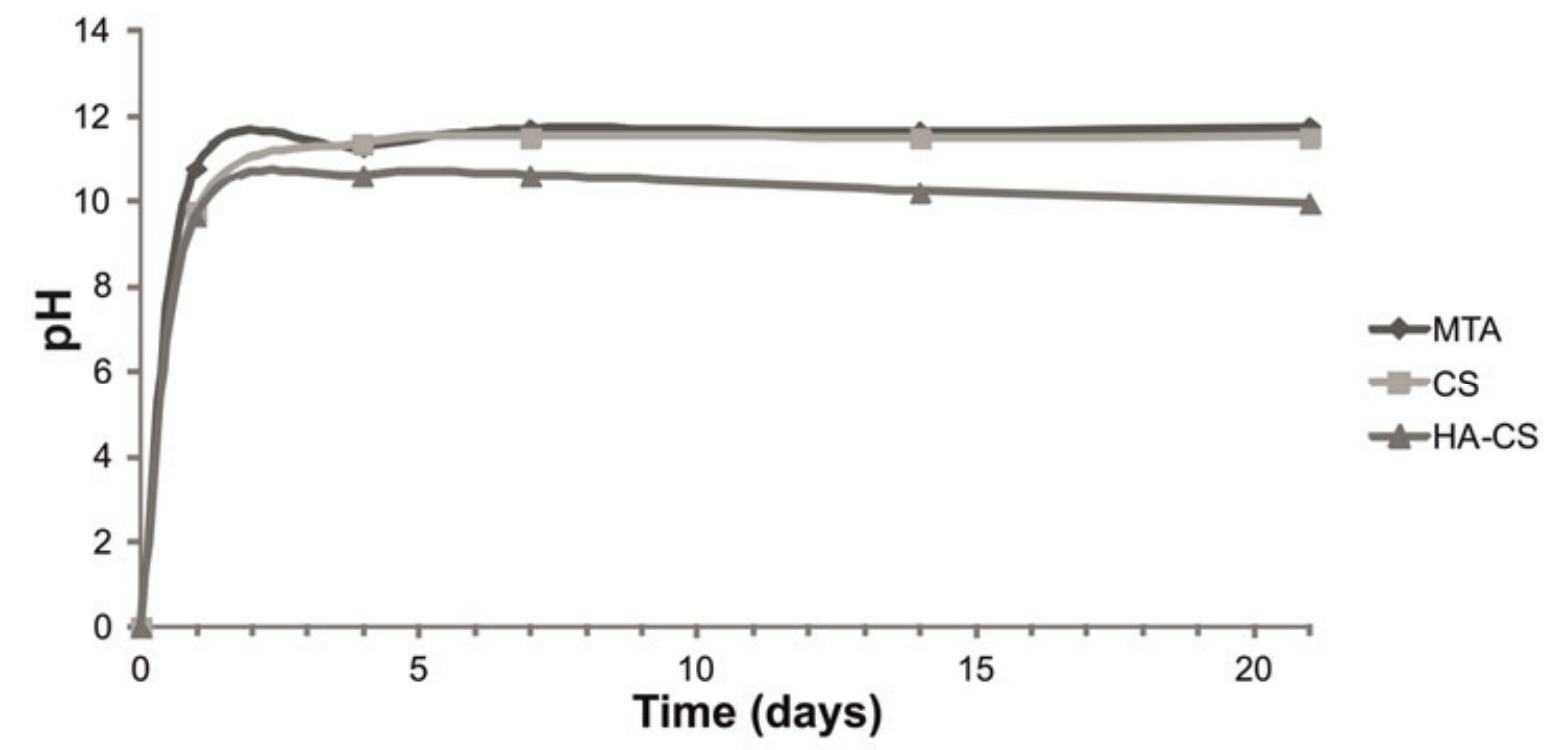

This article is protected by copyright. All rights reserved. 


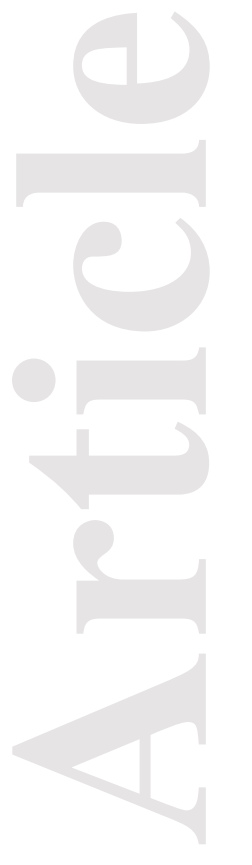

A)
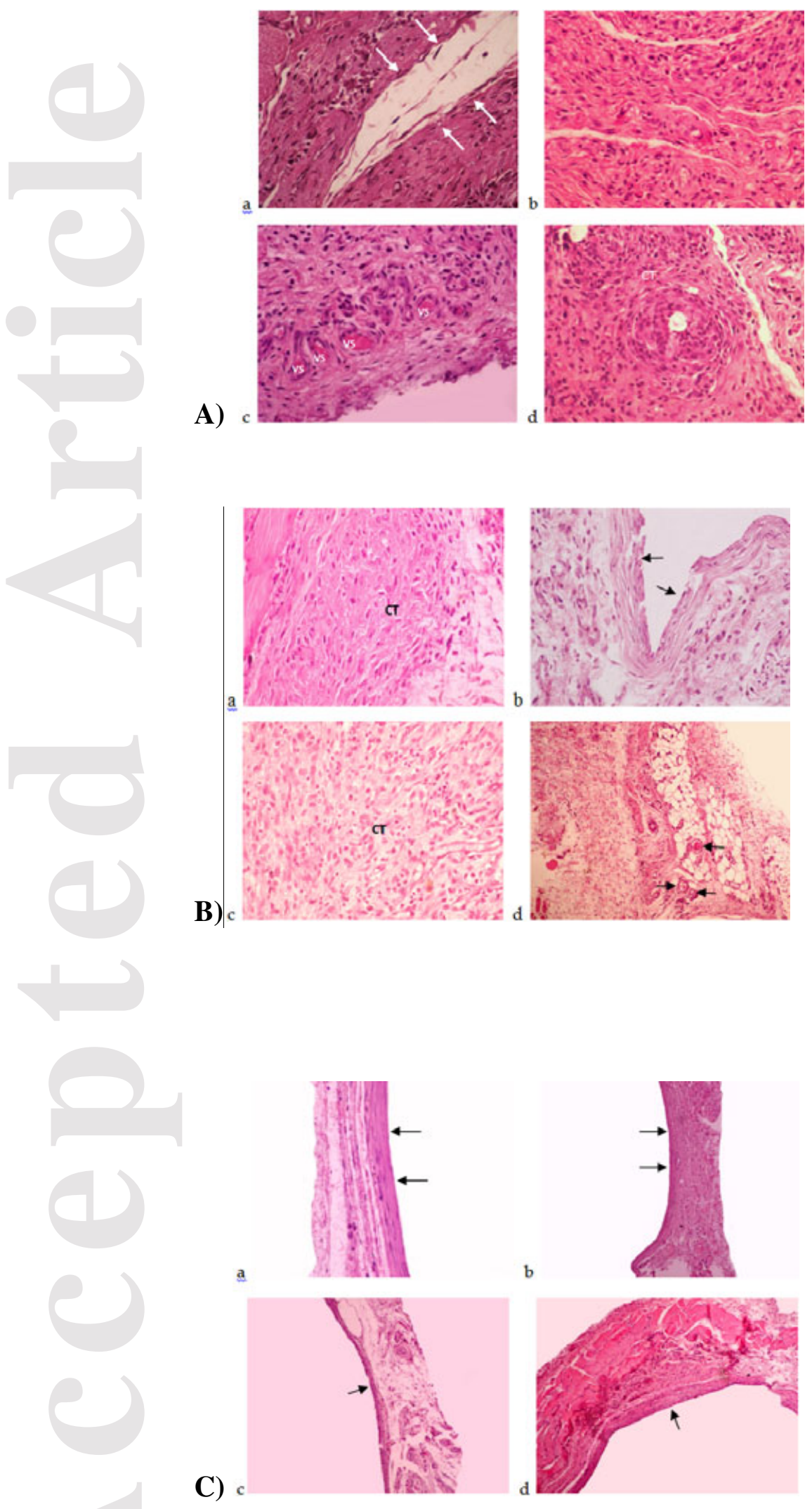

This article is protected by copyright. All rights reserved. 

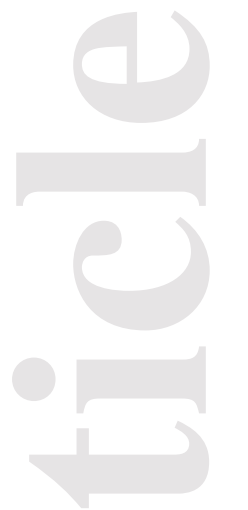

a
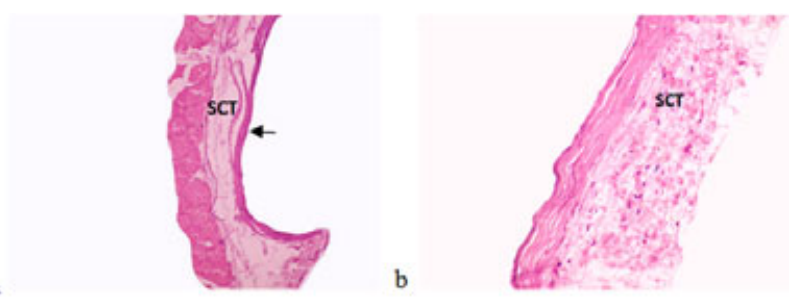

D) c
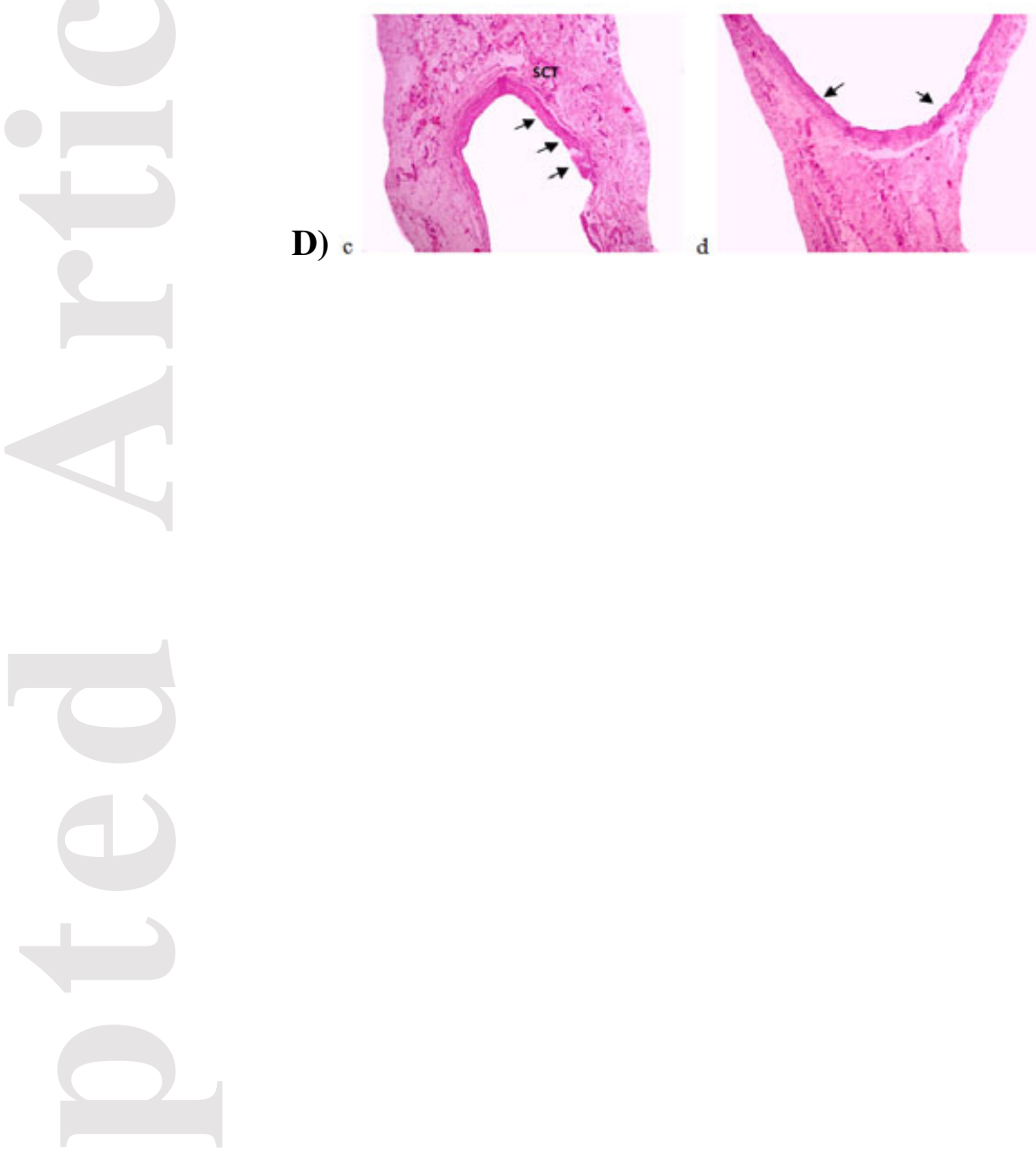

This article is protected by copyright. All rights reserved. 